find any example among cycles of this type that could provide a starting-point for an explanation of the observations on acute leukaemia and neuroblastoma.

As well as these imposed responses, there are seasonal cycles in a number of physiological factors which are controlled by biological clocks within man himself. Seasonal cycles in the degree of platelet stickiness, the level of antidiuretic hormone, the excretion of the metabolic products of steroid hormones, etc. (Tromp, 1963), are likely to be the result of internal cycles whose only reference to the environment is for synchronization. It is unknown whether these cycles affect disease, but they are large enough and occur in substances that are known to affect the progress of neoplastic disease. It is in such physiological cycles that the explanation of the observed changes in neuroblastoma seems likely to be found.

\section{Summary}

Deaths from neuroblastoma are more common in the summer months in England and Wales than in the winter. The summer excess in mortality for all patients is $32 \%$; it is found in males and females, and in children and adults. The seasonal pattern may be due to a physiological mechanism which influences the activity of certain forms of neoplastic disease.

ADDENDUM.-Since this paper was written two series of patients with neuroblastoma have been analysed where the date of diagnosis was recorded. At the Children's Orthopaedic Hospital and Medical Centre, Seattle (72 cases), there were $5.7 \%$ more diagnoses in the months April-September than in October-March. At the Los Angeles Children's Hospital (111 cases) there were $13.4 \%$ more diagnoses in the months AprilSeptember than in October-March. I am grateful to these two institutions for the use of their data.

I am grateful to the General Register Office of England and Wales, who have undertaken the very large amount of clerical labour necessary to produce the copies of the death centificates on which this study was based; and also to a Working Party appointed by the Medical Research Council for access to their case records. I also wish to thank Professor J. N. Morris and my scientific and clerical colleagues of the M.R.C. Social Medicine Research Unit for much help.

Requests for reprints should be addressed to Dr. J. A. H. Lee, Department of Preventive Medicine, University of Washington, Medical School, Seattle, Washington, 98105, U.S.A.

\section{REFERENCES}

Allan, T. M. (1966). Brit. med. 7., 1, 673.

Lee, J. A. H. (1962). Ibid., 1, 1737 .

(1967). In Progress in Clinical Cancer, edited by I. M. Ariel, vol. 3 , in press. New York.

and Gardner M. (1965). In Current Research in Leukaemia, edited by F. G. J. Hayhoe, p. 266. Cambridge.

Tromp, S. W. (1963). Medical Biometeorology, Weather, Climate, and the Living Organism. Amsterdam.

Wieberdink, J. (1957). Brit. F. Cancer, 11, 378.

Willis, R. A. (1960). Pathologv of Tumours, 3rd ed., p. 852 . London.

\title{
Herpes Simplex Encephalitis Treated with Intravenous Idoxuridine
}

\author{
A. D. EVANS, ${ }^{*}$ M.B., B.SC., DIP.BACT., M.C.PATH. ; O. P. GRAY, $†$ M.B., CH.B., M.R.C.P., D.C.H. \\ M. H. MILLER, $\ddagger$ B.M., B.CH., D.C.H. ; E. R. VERRIER JONES, $§$ M.B., B.CHIR., D.C.H. \\ R. D. WEEKS, $\mathbb{I}$ B.M., B.CH., F.R.C.S. ; C. E. C. WELLS, $\|$ M.B., B.S., F.R.C.P.
}

Brit. med. F., 1967, 2, 407-41J

In 1961 Herrmann, using the agar diffusion method which he had introduced with his colleagues (Herrmann et al., 1960) for the detection and bioassay of antiviral drugs, reported that plaque formation by the deoxyribonucleic acid (D.N.A.)-containing viruses of vaccinia and herpes simplex was inhibited by 5 -iodo-2'-deoxyuridine and by 5 -bromo-2'-deoxyuridine, the inhibition being reversed by thymidine. These synthetic nucleosides were inactive against ribonucleic acid (R.N.A.)containing viruses.

Experimental herpes simplex keratitis of rabbits was then found to be prevented or cured by the topical application of 5 -iodo-2'-deoxyuridine (idoxuridine) (Kaufman, 1962), and in a clinical study of 76 patients the drug was found to accelerate the healing of dendritic ulcers (Kaufman et al., 1962). Later experience was clouded by failure to distinguish between superficial and deep lesions of the cornea, and by including cases of uncertain cause as well as by the lack of critical comparison of treated and untreated cases. More recently a review of over

\footnotetext{
* Consultant Bacteriologist, Public Health Laboratory, Institute of Pathology, Cardiff Royal Infirmary.

+ Senior Lecturer, Department of Child Health, Welsh National School of Medicine.

$\ddagger$ Senior House Officer, Energlyn Hospital, Caerphilly.

$\$$ Registrar, Department of Child Heaith, Welsh National School of Medicine

If Consultant Neurosurgeion, United Cardiff Hospitals and Welsh Hospital Board.

II Consultant Neurologist, United Cardiff Hospitals and Welsh Hospital
} Board.
100 cases taken from statistically valid trials has confirmed the value of idoxuridine in treating superficial herpetic ulcers of the cornea, though it is ineffective in cases with deep stromal involvement (Leopold, 1965). It may prevent recurrent ulcers due to virus when corticosteroids are used for metaherpetic keratitis, iritis, and uveitis.

Calabresi et al. (1961) used idoxuridine in the treatment of advanced cancer, and found that the immediate toxic side-effects included leucopenia, stomatitis, and alopecia. Calabresi (1965) reported suppression of jennerian vaccination by idoxuridine and some beneficial effect on herpes zoster and on vaccinia gangrenosum. He thought that the systemic use of idoxuridine should be restricted to patients with cancer and to those with severe D.N.A.-virus infections. The drug might compete with thymidine-of which it is an analogue-in the synthesis of the nuclear D.N.A. of normal tissues, and it might thus be a remote cause of malignant metaplasia and of genetic injury.

Though the action of idoxuridine on the virus of herpes simplex is imperfectly understood, it is believed either to inhibit viral D.N.A.-polymerase or to be incorporated into viral D.N.A., thereby leading to the faulty transcription of messenger R.N.A. and to the synthesis of abnormal enzymes and proteins (Kaplan et al., 1965 ; Prusoff et al., 1965).

Against this background of uncertain antiviral activity and of possible human toxicity it was decided to use intravenous idoxuridine in a case of herpes simplex encephalitis from which 
recovery was thought to be unlikely. The natural history of this disease is unpredictable, but it has a high mortality rate and a risk of serious morbidity in those who survive (British Medical fournal, 1966).

During a 10-day period of close observation no variation was found in the clinical status of an 8-year-old girl who had been virtually decorticate for six weeks. . Brain biopsy was then performed, and was followed by the first of five intravenous doses of idoxuridine. Thirty-six hours later she was conscious and would open her eyes or protrude her tongue on command. During the following week she began to recognize members of her family, to speak, and to regain some power in her paralysed limbs. After the first month her progress slowed down, and it seemed improbable that she would recover fully.

The diagnosis of herpes simplex encephalitis was made by serological tests and by isolating the virus from material obtained at brain biopsy. Its identity was confirmed by neutralization and by biological tests. Complement fixation with the antigen of herpes simplex showed a rising titre of antibody from $<1 / 8$ on the seventh day of illness to $1 / 128$ on the 22 nd day.

The results of simultaneous chemical and histological examination of biopsy material were consistent with a diagnosis of viral encephalitis.

Further virus studies on frozen material, cultures of which were delayed for nearly 24 hours owing to transit by road and rail, were negative, thus underlining the need for immediate transfer of the specimen from the operating-theatre to the laboratory.

\section{Case Report}

An 8-year-old girl was admitted to a peripheral hospital on 29 July 1966. She had been ill for 48 hours with headache and loss of appetite. On the morning of admission she vomited, complained of giddiness, and was unable to stand when she got out of bed. Later she seemed dazed, could not speak, her eyes rolled, and she was trembling but did not lose consciousness.

She had been healthy before this illness. Her parents, three brothers, and two sisters were all well at the time; a school friend had recently started chicken-pox (varicella), which the patient herself had had four years earlier.

On admission she was conscious, alert, and co-operative, complaining of headache. Temperature $39^{\circ} \mathrm{C}$., pulse 140, and respirations 20. Slight neck stiffness and Kernig's sign were found. The optic fundi were normal, and the remainder of the neurological examination showed nothing abnormal. The pharynx and prominent tonsils were hyperaemic. There was no rash, and no ulcers were seen on mucous membranes. Lymph nodes were not enlarged, and liver and spleen were not palpable. Heart, lungs, abdomen, and urine were found to be normal.

Six hours after admission she had a fit. Next day she was drowsy, but was co-operative when roused. Fever up to $38.5^{\circ} \mathrm{C}$. persisted, and the signs of meningitis had increased. Her left leg was weak but she could stand without support. During the next 72 hours she became stuporous, and by 2 August was deeply unconscious. She was transferred to Cardiff Royal Infirmary. As the signs of left hemiplegia were increasing, and the electroencephalogram showed a focus in the right anterior quadrant against a background of widespread slow waves throughout both hemispheres, a right carotid angiogram was done by Dr. A. S. Bligh on the evening of her transfer to Cardiff. It was normal.

She had been treated with penicillin and sulphadiazine since $29 \mathrm{July}$, when the first lumbar puncture had supported the clinical diagnosis of viral meningitis. Anticonvulsant therapy was added after her fit. As the march and severity of her illness indicated intracerebral spread of the infection hydrocortisone and later adrenocorticotrophin were given as treatment for encephalitis.

During the next week she remained deeply comatose, with low fever, neck stiffness, and increasing spasticity of her left arm and leg. The left plantar response was extensor. Localized twitching of her face or limbs began on 5 August; it was short-lived and more often left-sided. Swallowing and cough reflexes returned by 10 August. Thereafter her temperature returned to normal, but she was unresponsive to all save the strongest stimuli, and twitching of her left hand was continual. Her eyes sometimes opened and appeared to watch her surroundings briefly, but she showed no constant response to any form of visual or auditory stimulus. Her left arm and leg were densely plegic. She was mute. The pupils were equal and reacted-normally to light, and the optic fundi remained normal. Brisk jaw jerk, sucking, and grasp reflexes were present. The liver edge became palpable 4 to $5 \mathrm{~cm}$. below the costal margin.

Corticosteroid therapy was stopped on 9 September, but cloxacillin and primidone were continued. On daily observation from this date by one of us (C. E. C. W.) there was no alteration in her decorticate state (Fig. 1). On 20 September biopsy of right

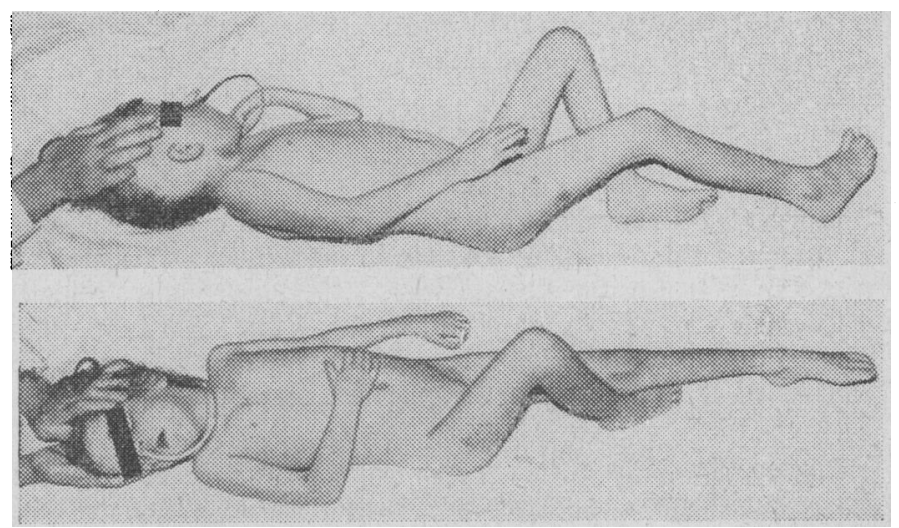

Fig. 1.- Herpes simplex encephalitis in a girl aged 8 years. 19 September 1966 ( 55 th day of illness). Mute, akinetic, dense left hemiplegia. Tonic neck reflexes.

frontal cortex was performed under nitrous oxide and halothane anaesthesia. A cylinder of tissue measuring 2 by $1 \mathrm{~cm}$. was obtained and was divided into four approximately equal parts. Two were placed in a container packed with dry ice and a third was fixed in $10 \%$ formol-saline. These were sent by train to London for viral, chemical, and histological study. The fourth part was examined at once in the public health laboratory in Cardiff and prepared for virus culture.

On the afternoon of 20 September, approximately six hours after biopsy, an intravenous infusion of $1.5 \mathrm{~g}$. of idoxuridine in dextrosesaline was given over eight hours. Four similar infusions were given, on $22,24,26$, and 28 September. The idoxuridine was prepared

Fig. 2. - Photograph 1966 (77th day of ill ness). Idoxuridine 1.5 g. in dextrose-saline solution was given intravenously on alternate days for five doses (total dosage 7.5 g.) from 20 to 28 September inclusive. 
for intravenous infusion according to the method described by Calabresi et al. (1961), and the total dose of the drug was estimated on the basis of $500 \mathrm{mg} . / \mathrm{kg}$. body weight.

On the morning of 22 September, some 36 hours after the first dose of idoxuridine, she responded vocally to painful stimuli, opened her eyes, and put out her tongue on command. During the next week she was restless and noisy, grinding her teeth, but became increasingly aware of her surroundings. By 29 September she recognized her parents and her sister, calling them correctly by name. The spasticity of the left arm and leg diminished with return of voluntary power to the hand and of limited speech.

During the next month her rate of progress slowed down and she seemed likely to remain severely handicapped both intellectually and physically (Fig. 2).

\section{Investigations}

On her admission the haemoglobin was $11.6 \mathrm{~g} . / 100 \mathrm{ml}$. and white cells $8,200 / \mathrm{cu}$. mm. (polymorphs $73 \%$, lymphocytes $26 \%$, monocytes 1\%). Regular counts were made during and after idoxuridine therapy. No significant variation in haemoglobin, total white cell, and platelet estimations was found. Small numbers of myelocytes were reported in the films of 26 and 28 September$7 \%$ and $1 \%$ respectively-but thereafter the differential counts were normal.

Blood sugar was $150 \mathrm{mg}$. and blood urea $25 \mathrm{mg} . / 100 \mathrm{ml}$. (on admission). Liver function (23 August): bilirubin $0.2 \mathrm{mg}$., zinc sulphate turbidity 10 units, thymol turbidity 1 unit, alkaline phosphatase 9.7 King-Armstrong units $/ 100 \mathrm{ml}$. Serum alanine transaminase 55 units $/ \mathrm{ml}$. Liver function ( 3 October): bilirubin $<0.5$ mg. ; total protein 6.5 g. (albumin 3.6 g.) ; thymol turbidity 4 units ; alkaline phosphatase 15 King-Armstrong units $/ 100 \mathrm{ml}$. Serum alanine transaminase 21 units, serum aspartate transaminase 20 units/ml.

Chest and skull $x$-ray pictures (on admission) were normal. Right carotid angiogram (2 August) was normal.

Lumbar puncture on four occasions showed clear cerebrospinal fluid under increased pressure $>180 \mathrm{~mm}$. of water. Cultures were sterile on each occasion, and after six weeks' incubation were sterile for Mycobacterium tuberculosis. Cytological and chemical findings were as follows: 29 July -2 red cells, 37 white cells/cu. mm. ; protein $25 \mathrm{mg}$., sugar $75 \mathrm{mg}$., chlorides $660 \mathrm{mg} . / 100 \mathrm{ml}$. $30 \mathrm{July}-$ 12 red cells, 67 white cells/cu. mm. ; protein $30 \mathrm{mg}$., sugar $65 \mathrm{mg}$., chlorides $630 \mathrm{mg} . / 100 \mathrm{ml}$. 12 August-15 red cells, 15. white cells/cu. mm. ; protein 75 mg., sugar 65 mg., chlorides $680 \mathrm{mg} . /$ $100 \mathrm{ml}$.; Lange 5444211100. 17 August -2 red cells, 0 white cells ; protein $75 \mathrm{mg}$., sugar $80 \mathrm{mg}$., chlorides $700 \mathrm{mg} . / 100 \mathrm{ml}$.; Lange 1110000000 . The cardiolipin Wassermann reaction and the Reiter protein-complement-fixation test were negative in the fluids collected on 29 July and 12 August. The Kahn reaction, cardiolipin Wassermann reaction, and Reiter protein-complement-fixation test were all negative in the blood on 29 July.

Electroencephalograms were recorded on four occasions. 2 August -high-voltage delta and subdelta waves were present in all leads; the slowest waves were focal in the right anterior quadrant. 5 August-runs of high-voltage slow waves followed by flattening appeared regularly at intervals of five seconds; bursts of spike activity which coincided with facial twitching were recorded from the right motor area. 14 September-all right-sided leads showed extreme flattening; irregular slow waves of moderate voltage appeared on the left. 30 September-the record was generally flat, with less marked asymmetry between leads from the two hemispheres.

\section{Virus Serology}

Complement-fixation tests with the antigens of influenza A, B, and C, adenovirus, $Q$ fever, psittacosis-L.G.V. group, lymphocytic choriomeningitis, mumps $\mathrm{S}$ and $\mathrm{V}$, Mycoplasma pneumoniae, respiratory syncytial virus, parainfluenza 3 , and the Paul-Bunnell reaction were consistently negative on 2,5 , and 17 August, 12 September, and 1 October. The cytoplasma modifying antibody (dye test) for toxoplasmosis was negative on 2 and 17 August.

A rising titre of antibody was shown by complement fixation with the antigen of herpes simplex. The titres obtained were:
$<1 / 8$ (2 August), 1/64 (5 August), and 1/128 (17 August, 21 September, and 1 October).

\section{Virus Isolation}

Part of the tissue obtained by cortical biopsy on 20 September was prepared immediately in the public health laboratory at Cardiff Royal Infirmary. It was ground in a Griffiths tube with Hanks's solution to make an approximately $10 \%$ suspension. This was inoculated into $\mathrm{HeLa}$ and second-passage monkey kidney cells. Typical cytopathic effects were seen after three days' incubation. The identity of the virus was confirmed as herpes simplex by neutralization tests with specific antiserum.

The brain suspension was also inoculated on to the chorioallantoic membrane of 11-day-old hen eggs. Characteristic pocks developed after five days. The intraperitoneal inoculation of suckling mice with $0.05 \mathrm{ml}$. of suspension was followed after four days by ascending spastic paralysis.

A similar piece of biopsy material was packed in a container with dry ice and sent by train on the same day to Dr. J. A. Dudgeon at the Hospital for Sick Children, Great Ormond Street, London. It was found to be well packed and frozen hard on arrival, and was put immediately into a wide range of cell cultures, suckling mice, and on to rabbit's cornea. After passage no evidence was found of herpes simplex virus.

\section{Chemical and Histological Findings}

Frozen material from the brain biopsy on 20 September was examined chemically by Professor J. N. Cumings at the Institute of Neurology, Queen Square, London. He interpreted the findings as being possibly due to an encephalitis in which damage to the cortex had been more severe than that to the white matter.

The chemical results, expressed as g./100 g. of dry tissue, are shown in the Table.

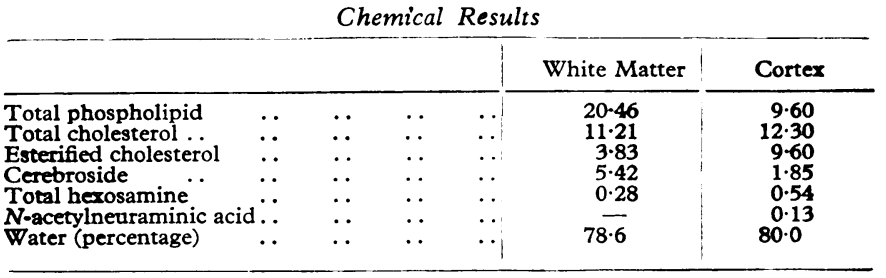

The results of thin-layer chromatography were as follows : white matter-normal phospholipid pattern; cholesterol esters showed a marked increase above normal. Cortex-normal phospholipid pattern with marked loss in all fractions; cholesterol esters showed a very large increase above normal; ganglioside pattern normal, but showed a loss of trisialoganglioside.

Material which had been fixed in formol-saline was examined histologically by Professor W. Blackwood at the Institute of Neurology. He thought that the appearances were those of a healing process of several weeks' duration in which nerve cells and surrounding tissue had been destroyed. He found the changes compatible with herpes simplex encephalitis but not diagnostic of it. His reported findings were as follows: "The leptomeninges and cortical vessels did not show any abnormality. The cortex was severely damaged. Layer one was replaced by swollen astrocytes; deep to this all the rest of what appeared to be cortex was replaced by a loose network of astrocytes and capillaries. Within the meshwork were occasional compound granular corpuscles, and around some of the small blood vessels were small mononuclear cells. Nerve cells and inclusion bodies were not seen. Endothelial hyperplasia was not a noticeable characteristic of the capillaries. The white matter was looser in texture than usual ; the astrocytes were hypertrophied."

\section{Conclusions}

This case is reported for two reasons: firstly, as an example of the diagnostic scope of brain biopsy when multiple analyses are made-viral, histological, chemical ; and secondly, as an 
account of the sytemic use of idoxuridine in the treatment of a severe D.N.A.-virus infection, herpes simplex encephalitis.

The place of idoxuridine in the chemotherapy of viral encephalitis, with or without corticosteroids, must await further trial; at least the facts of this case suggest that it may have antiviral action within the central nervous system.

As the chemotherapy of virus disease advances drugs are likely to be developed which are type-specific. Early identification of virus will be important. Brain biopsy, with the technique of Blackwood and Cumings (1959), is a safe and reliable procedure, but successful isolation of virus may depend on the speed with which material reaches the laboratory.

ADDENDUM.-Since this report was submitted for publication Breeden et al. (1966) have described a case of herpes simplex encephalitis in a middle-aged man who recovered after treatment by cerebral decompression and a seven-day course of idoxuridine.
Our thanks are due to Professor W. Blackwood for the histological report ; to Professor J. N. Cumings for the chemical report; to Dr. J. A. Dudgeon and Dr. N. J. Legg for the virus studies on the material obtained by brain biopsy ; and to Dr. D. G. Fleck for the serological tests for toxoplasmosis.

\section{REFERENCES}

Blackwood, W., and Cumings, J. N. (1959). Lancet, 2, 23.

Breeden, C. J., Hall, T. C., and Tyler, H. R. (1966). Ann. intern. Med., 65, 1050 .

Brit. med. F., 1966, 1, 1497.

Calabresi, P.'(1965). Ann. N.Y. Acad. Sci., 130, 192.

Cardoso, S. S., Finch, S. C., Kligerman, M. M., von Essen, C. F., Chu, M. Y., and Welch, A. D. (1961). Cancer Res., 21, 550 . Herrmann, E. C., jun. (1961). Proc. Soc. exp. Biol. (N.Y.), 107, 142. Herrmann, E. C., Jungliks, J., Engle, C., and Perlman, P. L. (1960). Ibid., 103, 625. Kaplan, A. S., Ben-Porat, T., and Kamiya, T. (1965). Ann. N.Y. Acad. Sci., 130, 226.

Kaufman, H. E. (1962). Proc. Soc. exp. Biol. (N.Y.), 109, 251.

Martola, E. L., and Dohlman, C. (1962). Arch. Ophthal., 68, 235. Leopold, I. H. (1965). Ann. N.Y. Acad. Sci., 130, 181.

Prusoff, W. H., Bakhle, Y. S., and Sekely, L. (1965). Ibid., 130, 135.

\title{
Evaluation of Autogenous Vein Bypass Grafts for Femoro-popliteal Arterial Occlusion
}

\author{
R. M. BADDELEY,* M.B., CH.B., B.SC., F.R.C.S. ; L. J. LAWSON,* M.B., CH.B., B.SC., F.R.C.S. \\ F. ASHTON,* CH.M., F.R.C.s. ; G. SLANEY,* CH.M., F.R.C.S.
}

Our experience and dissatisfaction with arterial homografts and synthetic bypass prostheses for femoro-popliteal occlusive arterial disease have already been published (Ashton et al., 1962); they concurred with the opinions of other surgeons in this field (Edwards, 1960 ; Taylor, 1962 ; Cockett and Maurice, 1963 ; Irvine et al., 1963 ; Szilagyi et al., 1964). As a result these techniques were abandoned and replaced by autogenous vein bypass grafts or vein patch thromboendarterectomy. This paper reports the results of 87 femoro-popliteal autogenous vein bypass grafts performed in the subsequent four-year period.

\section{Case Material}

These 87 femoro-popliteal bypass grafts with reversed autogenous saphenous vein were carried out between January 1962 and July 1965. The progress of these cases up to 31 January 1966 has been reviewed in all but six deceased patients. With the exception of two cases of traumatic arterial injury the operations were performed for atherosclerotic arterial occlusive disease.

All patients had intermittent claudication severe enough to halt them after walking 150 yards (135 metres) or less along a flat hospital corridor at their " normal" pace ; in most cases the stopping distance was less than 100 yards (90 metres). This empirical test was carried out immediately after the subjects' arrival in hospital to avoid the benefit a period of bed rest might have had on exercise tolerance. In all patients popliteal and pedal pulses were absent and in 43 limbs there was rest pain with trophic changes in the foot.

Arteriography by the Seldinger or translumbar technique was carried out in each case. Additional arteriography by direct

* Department of Surgery, Queen Elizabeth Hospital, Birmingham 15, and the University of Birmingham Medical School. injection into the femoral artery was occasionally employed to assess the details of the popliteal run-off.

At the follow-up examination grafts were denoted as successful and patent if pulsation was present in the graft itself or if pedal pulses were present. This was usually accompanied by relief of intermittent claudication and other evidence of ischaemia, though in two patients with still patent grafts this was not so; they presumably had distal small-vessel disease. Failed grafts showed loss of graft and pedal pulses and, in many but not all, recurrence of symptoms.

\section{Surgical Technique}

This is similar to that of Kunlin (1951). The ipsilateral long saphenous vein is dissected free from the subcutaneous fat through two incisions placed over it in the upper and lower thirds of the thigh; undercutting of the skin flaps must be avoided and particular care taken not to constrict the vein when its tributaries are ligated with fine silk. After removal the vein is irrigated and distended with a solution of normal saline containing $0.1 \%$ procaine and heparin in 50 units $/ \mathrm{ml}$.

The reversed saphenous vein is anastomosed to the popliteal artery end-to-side, but this anastomosis is left incomplete to permit subsequent flush-out manœuvres. Taking great care to avoid twisting, the vein is then passed subcutaneously to the groin, where the erstwhile distal end is anastomosed to the common femoral artery end-to-side. Before completion of the upper anastomosis "back-bleeding" from the profunda artery and flushing down the common femoral artery are carried out. This anastomosis is completed, and temporary blood flow down the graft is then used to flush out any clot, after which it is reclamped at its upper end and emptied digitally. The distal run-off is "back-bled," reclamped, and this anastomosis is then completed; the clamps are removed and blood flow down the 